\title{
The Interacting Mechanism of Government Science and Technology Supporting Mechanism on Strategic Emerging Industry Ecology Innovation
}

\author{
Wang Yinghua, Wang Hongqi and Wang Xueyuan \\ School of Management, Harbin University of Science and Technology, \\ Heilongjiang Harbin 150080 \\ Wangxueyuan1024@126.com
}

\begin{abstract}
This paper reveals the connotation of the strategic emerging industry innovation and the function of government science and technology support mechanism, and then analyzes evolution process and upgrade condition of strategic emerging industries ecology innovation. Accordingly, technology support mechanism and strategic emerging industry ecological innovation performance evaluation system are designed; through the questionnaire design, collection and overall, using structural equation analysis method, it's confirmed that the science and technology support mechanism has significantly positive effect on innovation ecosystem, and the guiding mechanism has a significant effect on technology and product development, technical service mechanism plays a significant role in technology transfer and docking, while the technology cultivation mechanism has a significant role on technology marketing and industrialization, and exceeding the expectations that coordination mechanism only actively promote technology and product development.
\end{abstract}

Keywords: government science and technology supporting mechanism; strategic emerging industry; ecology innovation; interacting mechanism

\section{Introduction}

Regional strategic emerging industry refers to the industry in the growth stage with the core characteristics regional, emerging and strategic features, which plays strategic guiding role for regional economic, technological, social and ecological development. As the key to the development of regional economy and science \& technology, its development is received great attention from the government, industry and academics.

The research on regional strategic emerging industries mainly focuses on industrial characteristics [1], the integration with traditional industry [2], industrial innovation [3], while advanced studies on eco-innovation are lack; McDonough and Braungart (2002) considered that the realization of ecological validity required internal optimization [4], but Stead $(2004,2010)$ states that it needs further organic connection with external environment [5-6]. Current research on the regional strategic emerging industries ecology innovation has focused on technical aspects, while studies on how to realize effective matching and joint at different stages of innovation, and the effective integration of industry internal and external environment are few.

Marko'czy and Deeds (2009) consider that the combination of two areas can enrich management theory and methods in respective field [7], Zahra and Newey (2009) further emphasizes that the integration of different areas is a very complicated problem, which needs considering the characteristics of different stages, and developing the management theory and method [8]. "Regional strategic emerging industries" and "scientific and technological support" are the research objects in two areas, and how to realize effectively 
interaction is an urgent problem needs exploring. However, traditional research focuses mainly on the study of overall strategy and management methods [9], such as tax [10] and financial aspects [11], but did not distinguish eco-innovation system stages and their specific characteristics \& situation, few researches have done on different government supporting ways and the matching with eco-innovation in different phases. In addition, there is a lack of quantitative analysis results to support various supporting mechanism research [12].

Therefore, combing of qualitative and quantitative method, and theory and practice calculation methods, can provide effective decision-making basis and method support to improve government science and technology supporting mechanism for regional strategic emerging industries ecological innovation, according to the different upgrading features of eco-innovation and the exploration of their relationship.

\section{Regional Strategic Emerging Industry Eco-Innovation Connotation and the Government Scientific and Technological Support Function}

\subsection{Regional Strategic Emerging Industry Eco-Innovation Connotation}

Regional strategic emerging industries eco-innovation refers to the regional strategic emerging industry not only realizes individual development in the stage of products and technological development, technological achievements transformation and industrialization, but also realize the efficient utilization of the resources, effective coordination of all aspects, and forming products group, project group, enterprise group, group teams to ensure industrial economic benefits and the low carbon consumption, the green and no pollution outputs, and other social and environmental benefits at the same time. The innovation activity ecology is to realize the effective development of the three links of innovation activities at the same time, ensure the effective convergence of each link, to achieve the efficient use of resources, to ensure the sustainable development of innovation activities.

\subsection{The Function of Government Science and Technology Support}

(1) Leading function. Innovation activities of strategic emerging industry have high risk, especially the technologies which can promote industrial upgrading and development, with overflow and the public characters. Therefore, it is necessary for government departments to offer direct supports, in order to reduce the risk of R\&D, stimulate the enterprise innovation behavior.

(2) Servicing function. Strategic emerging industries innovation requires the cooperation among a number of enterprises and subjects, in order to respectively play their advantages, realize the complementary function, improve innovation efficiency, and share R\&D risk. Therefore, at the beginning of the industrial innovation, the government can play a bypass and attachment role or offer innovation compensation service by tax policy, etc., realize the innovation achievements transformation and industrialization by providing support service for industry innovation activities to solve problems that enterprises encountered in innovating process.

(3) Cultivating function. Government encourages more industrial enterprises relying on technological innovation and creation to realize growth and development by establishing and improving industry bases, parks and clusters. By encouraging individual enterprise to enhance innovation capability realize the cultivation of strategic emerging industries innovation.

(4) Coordinating function. The government adopts a variety of measures, policy and system to realize collaboration and matching among different stages of innovation, 
different subjects, different policies, different system, etc., in order to support hierarchy innovation activities and realize persistent development.

\section{Conceptual Model Design and Measurement Index}

\subsection{The Measure Index System of Regional Strategic Emerging Industry Eco- Innovation Effects}

1. The conditions of regional strategic emerging industry eco-innovation evolution and upgrading. In order to achieve the orderly upgrading of strategic emerging industries, it should be made clear the specific conditions and requirements of industrial upgrading.

(1) The first condition for strategic emerging industries to upgrade is to reach a certain scale of industrial technology innovation, and form a series of innovative results, which is mainly for industry technological innovation. Strategic emerging industry belongs to industry with strong innovation capability, with high technical content, so for strategic emerging industry; the key is the core technology for the industrial development. Therefore, the technology effective matching should be achieved among different technology generation, different grades, different stages technology and products by technological innovation. Along technology R\&D and innovation upgrading track, strategic emerging industries experience three stages: From peripheral and related technology innovation or the general level innovation to a small number of enterprises making joint cooperation to carry out the core and key technology innovation, to industrial enterprises in the overall make a series of technology development to form technology standard. Strategic emerging industries in development process contiguously upgrade its technology level to protect the ecological innovation and sustainable development of the industry.

(2) The second condition for strategic emerging industries upgrading is the technology matching and transfer are active among industrial internal and external environment, which is mainly for technology transformation of the industry. Along the scientific \& technological achievements transferring and conversion track, strategic emerging industries mainly experience three stages: from single enterprise or a small amount of alliance, and supply chain enterprises internal transaction to industry enterprises internal active trading, to industry enterprise internal and external active transactions; from few policies for technology achievements matching and trade, to perfect system and effective implementation, to regular trading under the constraint specification. Industries achieve the upgrading and sustainable development through innovation and continuous improvement and optimization of technology transferring system.

(3) The third condition for strategic emerging industries upgrading is industrial technology achievements transformation, and the constant optimization and the hatching $\&$ growth of new enterprises. Science and technology innovation of industrial enterprises has been effectively realize economic and market value, the industry reserve force are formed for the future development, and the whole industry is in prosperity and active technology innovation atmosphere, the industrial is growing in scale, which help industry to achieve upgrading and sustainable development. The condition is mainly for industrialization. Strategic emerging industries realize technology industrialization good matching and industrial reserve forces construction and development in new areas through the two aspects adjustment and optimization: industrial technology upgrading of industry business expansion, and further realize the continual upgrading and sustainable development of strategic emerging industries.

According to the analysis of the above three aspects, it can be obtained the conditions and specific characteristics of regional strategic emerging industry eco-innovation upgrading, which is shown in Table 1. 


\section{Table 1. Upgrading Conditions and Characteristics of Regional Strategic} Emerging Industries

\begin{tabular}{|c|c|c|}
\hline \multirow{4}{*}{$\begin{array}{l}\text { Regional } \\
\text { strategic } \\
\text { emerging } \\
\text { industry } \\
\text { eco - } \\
\text { innovation } \\
\text { stage } \\
\text { upgrading }\end{array}$} & Upgrade condition & The stage of industrial innovation \\
\hline & $\begin{array}{l}\text { Industrial } \\
\text { Technology } \\
\text { Innovation }\end{array}$ & $\begin{array}{l}\text { * few enterprises carry out related and peripheral technological } \\
\text { innovation } \\
* \text { most enterprises make core and key technology innovation by } \\
\text { joint cooperation } \\
* \text { the whole industry carry out technical development and form } \\
\text { technical standards }\end{array}$ \\
\hline & $\begin{array}{l}\text { Industry technology } \\
\text { matching or } \\
\text { transferring activities }\end{array}$ & $\begin{array}{l}\text { * from single enterprise or supply chain enterprise transaction to } \\
\text { internal active trading, to internal and external transactions } \\
\text { * from sporadic policies, to perfect system and effective } \\
\text { implementation, to regular trading under constraint specification }\end{array}$ \\
\hline & $\begin{array}{l}\text { Industrial technology } \\
\text { achievements achieve } \\
\text { industrialization }\end{array}$ & $\begin{array}{l}\text { * passive industrialization, active industrialization, two-way } \\
\text { matching } \\
\text { * technology industrialization, new company establishment, and } \\
\text { industry upgrading and development }\end{array}$ \\
\hline
\end{tabular}

2. Regional strategic emerging industries eco-innovation effects measuring index Regional strategic emerging industries eco-innovation mainly rely on enhancing technological innovation, promoting transformation and industrialization, so the concrete manifestation of the three aspects can reflect the level of eco-innovation development.

(1) Technological innovation performance. Enterprises should be able to obtain effective research and development achievements on the basis of receiving various government policies support. R\&D results include the quality of research and development, which means compared with the same field enterprises the number and quality of patents should have an advantage. Secondly, under the guidance of government, the research and development achievements of enterprises should have efficient resources utilization and environmental friendly characteristics and so on. Finally, the enterprise $R \& D$ results should be formed reserve for upgrading and product alternation.

(2) The achievement matching and transformation performance. Business achievements matching and transformation can be reflected by the activity of achievement transfer among industrial enterprises, the keys of which are process and result. Firstly, enterprises achievement matching and transferring activities should be active; secondly, technology transfer and matching activity is increasing among regional areas and other fields enterprises; finally, industrial technology transaction contracts and transaction volume continues to increase.

(3) Industrialization of achievements. Strategic emerging industries of eco-innovation industrialization should be reflected through three aspects: Firstly, all industrial enterprises revenue of new products or new product sales increase, realize business growth and development through innovation; secondly, enterprises derived from technology achievements continue increasing, and new products advent, form a more cooperative enterprises network or build many new businesses; finally, new product development promotes the upgrading and technological transformation of industrial enterprises, and the whole industry moves towards high-end value chain direction.

Through the above analysis, we can construct the evaluation index system and standard of strategic emerging industry enterprises eco-innovation development performance, which is shown in Table 2 . 
Table 2. Measure Index and Standard of Eco-Innovation Effect

\begin{tabular}{|c|c|}
\hline $\begin{array}{l}\text { Three stages of } \\
\text { eco-innovation }\end{array}$ & Measure index and standard \\
\hline $\begin{array}{l}\text { Technological } \\
\text { innovation }\end{array}$ & $\begin{array}{l}\text { *The number of enterprise patents is higher than the average level of other enterprises } \\
\text { * R\&D achievements have eco-environment friendly and resource high-utilization } \\
\text { character }\end{array}$ \\
\hline & *Form reserve for upgrading and a relatively perfect product alternation \\
\hline $\begin{array}{l}\text { Achievement } \\
\text { matching and } \\
\text { transformation }\end{array}$ & $\begin{array}{l}\text { * R\&D achievement transformations are active among industrial enterprises } \\
\text { *Achievements transferring activities among industry enterprises and external regional } \\
\text { enterprises are increasing }\end{array}$ \\
\hline transiomation & $\begin{array}{l}\text { *Technology trading volume and technology transaction contracts significantly increase } \\
\text { * Sales and revenue of new products continue growing }\end{array}$ \\
\hline Industrializatio & $\begin{array}{l}\text { *New company or subsidiary companies or enterprises cooperation are formed based on } \\
\text { new products, which promotes industrial prosperity and development }\end{array}$ \\
\hline $\mathrm{n}$ & $\begin{array}{l}* \text { New products drive industry structure and technology upgrading, the industry moves } \\
\text { towards high-end of value chain }\end{array}$ \\
\hline
\end{tabular}

\subsection{Index System of Science and Technology Support Mechanism}

(1) Guiding mechanism. First, the effectiveness of guiding mechanism should be reflected by whether the government introduced the relevant science and technology programs or plans to guide regional strategic emerging industries eco-innovation and development. The introduction of related plans or policies is the premise of ensuring the implementation of guiding mechanism, at the same time the policy system itself should be scientific, objective and comprehensive. Therefore, it should be checked in the process of planning whether there are multi subjects participating in discussion, such as government, universities, enterprises and research institutes, etc., and whether reach a consensus through multiple demonstration and communication; secondly, it should be checked whether the project can be completed in accordance with the expected budget, which can effectively reflect the discussion process scientificality; finally, whether achievements are effectively realized transformation and industrialization and whether effectively guide strategic emerging industrial eco-innovation should be used to reflect guiding mechanism effectiveness.

(2) Servicing mechanism. The effectiveness of servicing mechanism needs to be reflected in two aspects: the feeling of service reception and the quality of provided service. On the one hand, service accepted enterprise should be satisfied with resources sharing quantity and richness, and accept the service response time and problem solve price; on the other hand, whether the government has specialized departments and personnel who are responsible for the scientific and technological achievements matching and transferring, and whether these departments are able to effectively integrate all the resources and make good scheduling, will determine the government servicing mechanism effectiveness.

(3) Cultivating mechanism. Cultivating mechanism can be reflected by whether science and technology parks, industrial base can meet the enterprises demand, such as admission audit period, the audit process, and preferential policies and accepted service and the opportunity to cooperation and alliance with other enterprises after admission. Whether these policies are able to guide strategic emerging industry enterprises to play leading role, can effectively reflect a region government cultivating function. The other point is whether the strategic emerging industrial enterprises form a reserve for optimization, whether the whole industry moves toward the high-end of value chain, etc.,

(4) Coordinating mechanism. Coordination mechanism should be focused on the matching and integrating of the stages of development, transformation and industrialization. Whether different subjects realize effective cooperation and achieve the efficient utilization of resources, whether form a consensus among different actors in 
innovation field and target, whether industrial innovation activities formed effective matching with innovation management should be checked to reflect coordinating mechanism effectiveness.

Measurement indexes and standards of government guiding mechanism, servicing mechanism and cultivating mechanism and coordinating mechanism for strategic emerging industries eco-innovation can be seen in Table 3. According to actual condition of the enterprises and government departments give the score. Full compliance with actual condition will get 9 points, compared compliance with actual condition is 7 points, generally consistent with is 5 points, not in line with is 3 points, does not meet actual condition is 1 point.

Table 3. Mechanism Measurement Index and Standard

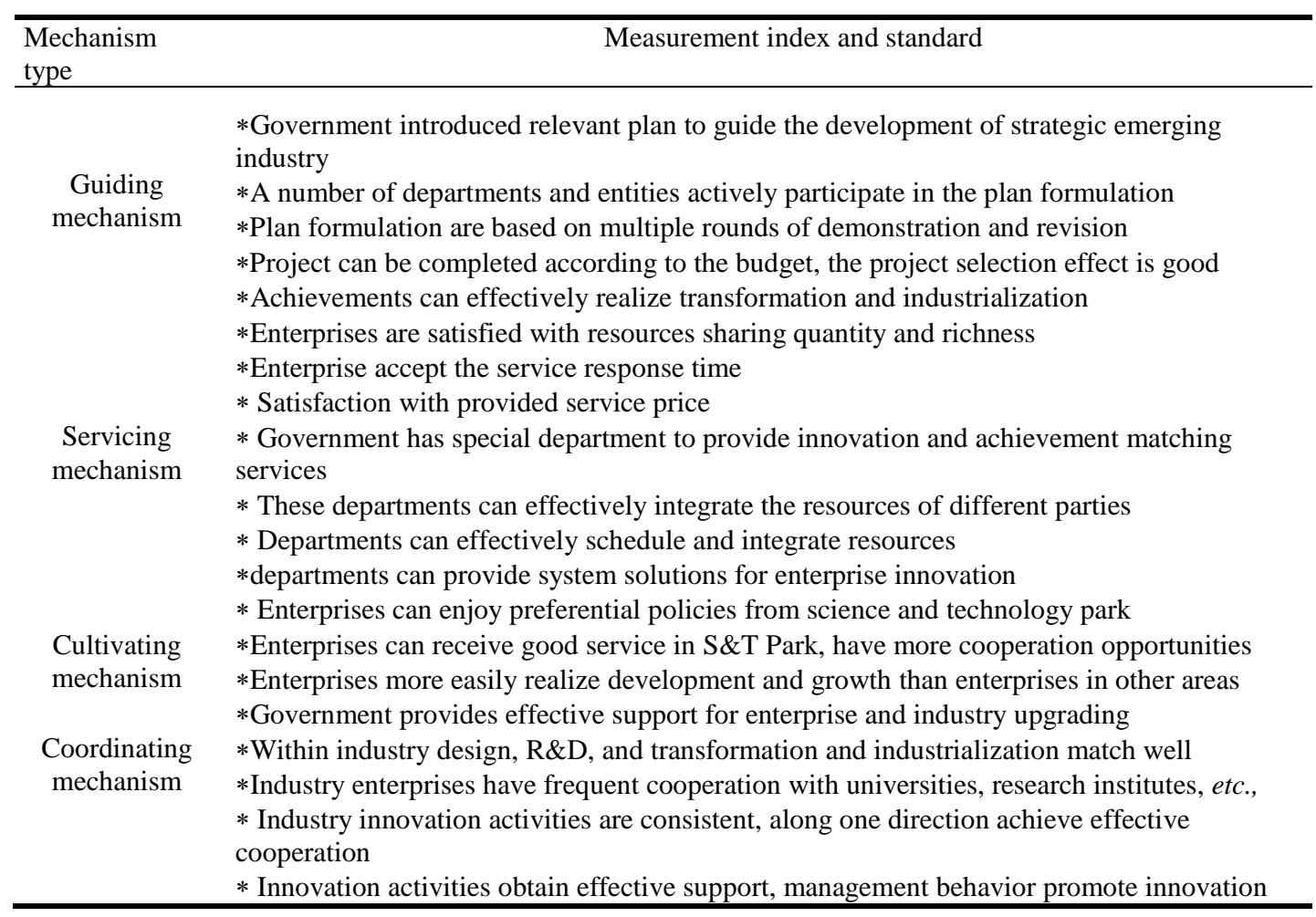

\subsection{Model Construction and Data Collection}

According to the three aspects of eco-innovation stages and government support mechanisms for strategic emerging industrial eco-innovation, this paper proposes that government guiding mechanism has a direct and significant influence on strategic emerging industries $R \& D$ activities; government servicing mechanism has a direct and significant influence on strategic emerging industries technology achievements transformation and matching; government cultivating mechanism has a direct and significant influencing on strategic emerging industry mercerization and industrialization; and government coordinating mechanism has direct and significant influence on strategic emerging industries R\&D, achievements transformation and industrialization.

In order to get specific data, selects personnel from relevant government departments or strategic emerging enterprise to fill the questionnaire form, which are collected by government departments that are responsible for auditing to guarantee the authenticity and objectivity. Government departments and enterprise personnel totally completed 112 valid questionnaires. Because the government personnel reviewed the questionnaire and unqualified questionnaires are asked to revision and make supplement, questionnaire obtained from government departments has high effectiveness. 
Personnel of government departments are main from science and technology management department, technical platform center, technology achievement transferring department; related strategic emerging industries consists high-end equipment manufacturing industry, information technology industry, biology industry, new materials and new energy, while the personnel from energy-saving and environmental protection and $f$ electric vehicles are few. The five areas are important strategic emerging industries in Heilongjiang Province, which can reflect the overall situation of strategic emerging industry innovation.

According to the degree that actual situation in line with the statements in questionnaire we can get the score of each index. Because the mechanism and the ecoinnovation effect are reflected by different problems, we use the simple average method to obtain the average value of the four different mechanism and three aspects of ecoinnovation effect.

In this paper, Amose7.0 software was adopted, use the collected data to calculate, according to the theoretical analysis of the model, the calculated results can be seen in table 4. The overall fitting effect of the model is good, the key fitting index of the model and the corresponding optimal values are shown in Table 5.

Table 4. Regression Results and Significance Test (preliminary)

\begin{tabular}{|c|c|c|c|c|c|}
\hline \multicolumn{2}{|c|}{ Interacting relationship } & Estimate & S.E. & C.R. & $\mathrm{P}$ \\
\hline S\&T servicing mechanism & $<---\mathrm{S} \& \mathrm{~T}$ guiding mechanism & .902 & .382 & 2.361 & $\begin{array}{c}.01 \\
8\end{array}$ \\
\hline Technology development (R\&D) & $<--\mathrm{S} \& \mathrm{~T}$ guiding mechanism & .378 & .051 & 7.391 & $* * *$ \\
\hline Achievement transferring and matching & <--- S\&T servicing mechanism & .808 & .057 & 14.197 & $* * *$ \\
\hline Technology industrialization & $<---\mathrm{S} \& \mathrm{~T}$ cultivating mechanism & .833 & .038 & 22.215 & $* * *$ \\
\hline Technology development (R\&D) & $<---\begin{array}{l}\text { S\&T coordinating } \\
\text { mechanism }\end{array}$ & .343 & .050 & 6.899 & $* * *$ \\
\hline Achievement transferring and matching & $<---\begin{array}{l}\text { S\&T coordinating } \\
\text { mechanism }\end{array}$ & .085 & .045 & 1.911 & $\begin{array}{c}.05 \\
6\end{array}$ \\
\hline Technology industrialization & $<---\begin{array}{l}\text { S\&T coordinating } \\
\text { mechanism }\end{array}$ & .064 & .037 & 1.736 & $\begin{array}{c}.08 \\
3\end{array}$ \\
\hline
\end{tabular}

Table 5. Fitting Effect Index (Preliminary)

\begin{tabular}{cccccc}
\hline Goodness of fit & CMIN/DF & RMR & GFI & CFI & RMSEA \\
\hline Index value & 0.698 & .060 & 0.978 & 1.000 & 0.000 \\
Standard value & $<3$ & $<0.1$ & $>0.9$ & $>0.9$ & $<0.1$ \\
\hline
\end{tabular}

Although the overall fitting effect is good, in significance inspection, it is found that the science and technology coordinating mechanism for technology transferring and matching, and the coordinating mechanism for technology industrialization influence significant did not pass the t-test at 0.05 level, which can be seen in Table 4 . Therefore, it is necessary to further optimize the model, optimizing the significance test value of modified model is shown in Table 6, the fitting effect judging index value is shown in Table 7. after optimization the model not only passed the goodness of fit test, also passed the t-test at 0.05 level, and the result has good significant.

Table 6. Regression Results and Significance Test (Optimized)

\begin{tabular}{|c|c|c|c|c|c|}
\hline \multicolumn{2}{|c|}{ Interacting relationship } & Estimate & S.E & C.R. & $\mathrm{P}$ \\
\hline$\overline{\text { S\&T servicing mechanism }}$ & $\begin{array}{ll}--- & \text { S\&T guiding mechanism }\end{array}$ & .352 & .069 & 5.090 & $* * *$ \\
\hline Technology development (R\&D) & $<---$ S\&T guiding mechanism & .378 & .051 & 7.391 & $* * *$ \\
\hline $\begin{array}{l}\text { Achievement transferring and } \\
\text { matching }\end{array}$ & $<---\quad$ S\&T servicing mechanism & .820 & .058 & 14.185 & $* * *$ \\
\hline
\end{tabular}




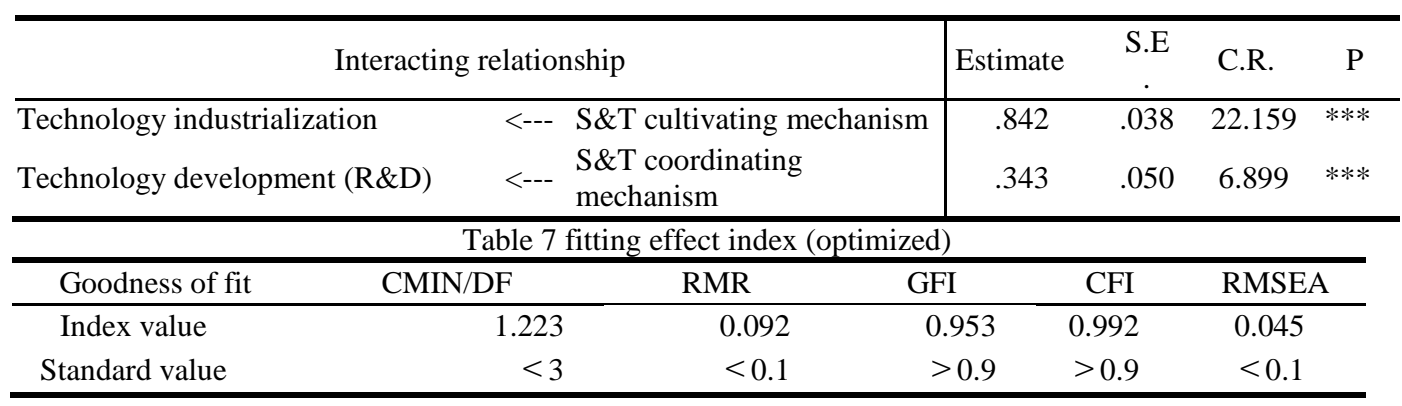

\subsection{Results Analysis}

According to calculated results, it can be seen that governments various mechanisms have significant influence on technology development (R\&D), technology achievements transformation and matching, technology industrialization. Servicing mechanism has more significant influence on achievement matching, cultivating mechanism has more significant influence on industrialization, and guiding mechanism has relatively small effect on R\&D and innovation.

The main reason for this phenomenon is that science and technology plan effect on $\mathrm{R} \& \mathrm{D}$ is relatively limited, enterprise behaviors are more influenced by market condition, but guiding mechanism still plays obvious and direct positive role on R\&D. Technical guiding mechanism has a certain influence on the servicing mechanism, guiding mechanism offer more resources for service integration, but coordinating mechanisms currently only has effect on technology development (R\&D), the influence on the achievement transferring and industrialization is not significant. From the above results, the following conclusions can be drawn:

(1) Science and technology supporting mechanism plays a positive and significant role in promoting strategic emerging industries innovation; therefore, it needs to improve ecoinnovation through the improvement of scientific and technology support mechanism.

(2) Coordinating mechanism should play a positive role in all stages, but currently the mechanism impact on transferring and industrialization stages should be improved.

(3) Various mechanisms should influence each other, while currently only guiding mechanism has significant influence on servicing mechanism, further should pay more attention between guiding mechanism and cultivating mechanism, and coordinating mechanism and guiding \& cultivating mechanism.

\section{Conclusion}

Based on the analysis of the function of S\&T support and the upgrading requirement of the three innovation stages, this paper puts forward the research hypothesis. Based on questionnaire investigation and structural equation modeling, we can get the conclusions: S\&T support mechanism has a positive role in promoting regional strategic emerging industry eco-innovation; the guiding mechanism plays a supporting role in technology development $(R \& D)$; servicing mechanism should be focused to play a supporting role in technology achievements transformation and cultivating mechanism should play a supporting role in achievement industrialization. Effective interaction between various mechanisms is not enough, which needs further optimization, in order to strengthen the organic connection of the various departments, various functions, and then effectively promote regional strategic emerging industry ecol-innovation. In this paper, the data of Heilongiiang Province were only used for analysis; it is difficult to reflect the overall situation of China. Therefore, in the future, should further explore the differences in eastern and western regions, in order to provide effective decision support for different parts government $S \& T$ management. 


\section{Acknowledgements}

This work has been supported by National Natural Science Foundation of China Fund Project (71173062), the National Natural Science Foundation of China Youth Fund Project (71403070); Heilongjiang Province philosophy social sciences innovation team construction plan (TD201203)

\section{References}

[1] L. Hui, L. Yifang, Q. Han, H. Yi, C. Wei and Y. Xianghua, "Research on Innovation-driven Development Path of Strategic Emerging Industries in China: Based on Beijing Biological Medicine Industry", Management review, vol. 12, (2014), pp. 20-28.

[2] X. Yongqing and Y. Yi, "Research on the Docking Path and Model between Traditional Enterprise and Strategic Emerging Industry”, Science of Science and Management of S. \& T., vol. 9, (2013), pp. 107115 .

[3] W. Shaobo, G. Ying and L. Dunhu, "Collaborative innovation research of strategic emerging industries from the perspective of knowledge innovation chain",Science \& Technology Progress and Policy, vol. 1, (2014), pp. 50-54.

[4] W. McDonough and M. Braungart, "Cradle to cradle: Remaking the way we make things", New York: North Point Press, (2002).

[5] W. E Stead and J. G. Stead, "Sustainable Strategic Management", New York: M. E. Sharpe Inc. (2004).

[6] J. G. Stead and W. E. Stead, "Sustainability comes to management education and research: A story of coevolution", Academy of Management Learning and Education, vol. 9, (2010), pp. 488-498.

[7] L. Marko'czy and D. L. Deeds, "Theory building at the intersection: Recipe of impact or road to nowhere", Journal of Management Studies, vol. 46, (2009), pp. 1076-1088.

[8] S. Zahra and L. R. Newey, "Maximizing the impact of organization science: Theory building at the intersection of disciplines and/or fields", Journal of Management Studies, vol. 46, (2009), pp. 1059-1075.

[9] L. Tie and H. Jun, "Technological and Economic Features of Emerging Industries with Strategies Importance and Reshaping Industrial Policy”, Academic Monthly, vol. 7, (2013), pp. 78-88.

[10] H. Tao, "Study of Financial and Taxation Policies on Promoting the Strategic Emerging Industry in China", Reformation \& Strategy, vol. 12, (2014), pp. 58-61.

[11] X. Jie and W. Xiaodong, "The Policy Research on Financial Support for Guangzhou's Strategic Emerging Industry", Science and Technology Management Research, vol. 12, (2014), pp. 37-40.

[12] Z. Zhiyong and B. Kexin, "Performance Efficiency Evaluation of Local Government on Green Innovation System in Manufacturing Industry”, Journal of Harbin University of Science and Technology, vol. 3, vol. 16, (2011), pp.116-120. 
International Journal of $u$ - and e- Service, Science and Technology Vol.9, No. 10 (2016) 